\title{
IMPLIKASI KEBIJAKAN FISKAL ERA ORDE BARU DAN ERA REFORMASI \\ DALAM MEWUJUDKAN PERTUMBUHAN INKLUSIF DI INDONESIA
}

\author{
JURNAL ILMIAH
}

Disusun oleh :

Hidsal Jamil

135020100111028

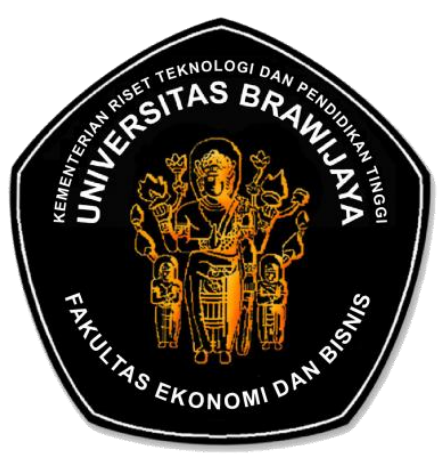

JURUSAN ILMU EKONOMI

FAKULTAS EKONOMI DAN BISNIS

UNIVERSITAS BRAWIJAYA

MALANG

2017 
Artikel Jurnal dengan judul :

\section{IMPLIKASI KEBIJAKAN FISKAL ERA ORDE BARU DAN ERA REFORMASI} DALAM MEWUJUDKAN PERTUMBUHAN INKLUSIF DI INDONESIA

Yang disusun oleh :

Nama

: Hidsal Jamil

NIM

: 135020100111028

Fakultas

: Ekonomi dan Bisnis

Jurusan

: S1 Ilmu Ekonomi

Bahwa artikel Jurnal tersebut dibuat sebagai persyaratan ujian skripsi yang dipertahankan di depan Dewan Penguji pada tanggal 8 Agustus 2017.

Malang, 14 Agustus 2017

Dosen Pembimbing,

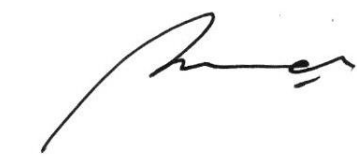

Dwi Budi Santoso, S.E., M.S., Ph.D

NIP. 196203151987011001 


\title{
IMPLIKASI KEBIJAKAN FISKAL ERA ORDE BARU DAN ERA REFORMASI DALAM MEWUJUDKAN PERTUMBUHAN INKLUSIF DI INDONESIA
}

\author{
Hidsal Jamil \\ Dwi Budi Santosa \\ Fakultas Ekonomi dan Bisnis Universitas Brawijaya \\ Email: hidzaljamil@gmail.com atau hidsaljamil@yahoo.com
}

\begin{abstract}
ABSTRAK
Penelitian ini memiliki dua tujuan utama yakni: (i) menguji inklusivitas pertumbuhan ekonomi di Indonesia; dan, (ii) menganalisis perbedaan implikasi kebijakan fiskal Era Orde Baru dan Era Reformasi dalam mewujudkan percepatan pertumbuhan inklusif di Indonesia. Dengan menggunakan metode estimasi parameter 3SLS (Three Stage Least Square), penelitian ini menemukan bahwa pertumbuhan ekonomi di Indonesia selama periode 1981-2016 masih belum inklusif. Temuan ini mengindikasikan bahwa peningkatan aktivitas ekonomi di Indonesia mengarah pada sektor yang bersifat padat modal (capital intensive). Selain itu, penelitian ini menemukan bahwa kebijakan fiskal baik di Era Orde Baru dan Era Reformasi memiliki implikasi yang berbeda dalam mewujudkan pertumbuhan inklusif di Indonesia. Peningkatan pertumbuhan ekonomi bersumber dari belanja kesehatan di Era Orde Baru dan belanja pendidikan di Era Reformasi. Sementara itu, penurunan pengangguran berasal dari belanja infrastruktur di Era Orde Baru.
\end{abstract}

Kata Kunci: Kebijakan Fiskal, Pertumbuhan Inklusif, Metode 3SLS.

\section{A. PENDAHULUAN}

Peran pemerintah sangat penting dalam mengerakkan aktivitas ekonomi agar perekonomian menuju kondisi yang diinginkan (Ismail et al, 2014). Peran pemerintah terutama dalam mencapai pertumbuhan ekonomi yang tinggi dapat melalui mekanisme pasar dan non-pasar. Peran pemerintah melalui mekanisme pasar terdiri dari kebijakan fiskal (melalui pengaturan belanja dan penerimaan negara) dan moneter (melalui pengendalian jumlah uang beredar dan tingkat suku bunga), sementara mekanisme non-pasar terdiri atas kebijakan di luar kebijakan fiskal dan moneter (melalui pembentukan regulasi dan perundang-undangan).

Sebagai salah satu bentuk peran pemerintah, kebijakan fiskal tidak hanya diarahkan guna mencapai pertumbuhan ekonomi yang tinggi. Kebijakan fiskal perlu menciptakan pertumbuhan ekonomi berkarakter inklusif sehingga dapat memberikan manfaat yang setara dan meningkatkan partisipasi masyarakat dalam pembangunan (Ramos et al., 2013). Dalam konteks ini, pertumbuhan ekonomi tetap penting, namun sangat tergantung pada kecepatan dan pola dari pertumbuhan ekonomi itu sendiri (Biswas, 2016).

Peran pemerintah melalui kebijakan fiskal telah terbukti dibanyak negara berkembang. Bukti pentingnya kebijakan fiskal dalam mempromosikan pertumbuhan inklusif terdapat pada studi yang dilakukan oleh David dan Patri (2013) di Mauritius, Estrada et al (2014) negara-negara di Asia, Lee dan Park (2014) di Amerika Latin. Akan tetapi di Indonesia sendiri, studi yang menghubungkan langsung antara kebijakan fiskal dan implikasinya terhadap pertumbuhan inklusif masih relatif belum ada. Studi yang telah dilakukan hanya memaparkan kegagalan pemerintah dalam mencapai pertumbuhan inklusif (lihat Hadi, 2012) atau paling tidak, mencari tahu penyebab pertumbuhan ekonomi di Indonesia kurang inklusif (lihat Dartanto, 2013; Anderson et al., $\mathrm{tt})$.

Lebih lanjut, penelitian ini bertujuan untuk menguji inklusivitas pertumbuhan ekonomi di Indonesia. Selain itu, penelitian ini juga difokuskan untuk membandingkan peran pemerintah-baik Era Orde Baru maupun Era Reformasi-melalui kebijakan fiskal yang mewujudkan percepatan pertumbuhan inklusif di Indonesia. Kebijakan fiskal tidak saja melalui pertimbangan rasionalitas ekonomi, namun melalui mekanisme politik yang dinamis (Ismail et al, 2014). Era Orde Baru menekankan kepemimpinan politik yang cenderung otoriter, sementara Era Reformasi mengarah pada kepemimpinan politik yang demokratis (Ricklefs, 2001). Dalam konteks Indonesia, Era Orde Baru dan Era Reformasi merupakan rezim dengan mekanisme politik yang jauh berbeda satu sama lain.

\section{B. TELAAH LITERATUR}

Peran pemerintah mengikuti evolusi kebijakan pembangunan dari waktu ke waktu (Biswas, 2016). Dalam sudut pandang konvensional, peran pemerintah mencakup tiga hal penting yakni (i) menyediakan barang publik; 
(ii) meredistribusikan pendapatan; dan (iii) menstabilisasi ekonomi (Musgrave dan Musgrave, 1989). Kemudian, dalam sudut pandang terbaru, dimulai sejak awal tahun 2000-an, peran pemerintah mencakup dimensi yang lebih luas. Pemerintah dituntut untuk menciptakan pertumbuhan ekonomi yang berkarakter inklusif dalam sebuah program terpadu untuk mencapai pertumbuhan ekonomi yang memampukan pelipatgandaan pendapatan per kapita dalam waktu singkat, tanpa mengabaikan keadilan distributif dan fokus yang tidak terbagi dalam pengurangan kemiskinan (Naqvi, 2012).

Dalam konteks pertumbuhan inklusif, peran pemerintah juga dibutuhkan dalam perbaikan distribusi pendapatan kelompok miskin. Ahluwalia dan Chenery dalam Santosa (1992), menyebutkan ada tiga strategi yang bisa ditempuh yaitu pertama, redistribusi konsumsi, dimana pemerintah pemerintah dapat melakukan pemotongan tingkat konsumsi kelompok kaya untuk disalurkan kepada kelompok miskin.Kedua, redistribusi investasi, dimana pemerintah dapat mengalihkan sumber daya masyarakat guna menambah tingkat kapital (asset) kelompok miskin. Ketiga, pembatasan upah, dimana dalam jangka pendek, akan dapat menambah pertumbuhan pendapatan dari kelompok kaya melalui perolehan profit, namun pada jangka panjang akan dapat meningkatkan pendapatan dari kelompok miskin karena adanya peningkatan produksi dari kelompok kaya.

Salah satu instrumen guna mewujudkan percepatan pertumbuhan inklusif adalah peran pemerintah melalui kebijakan fiskal. Kebijakan fiskal terdiri dua komponen utama yaitu kebijakan belanja dan kebijakan penerimaan. Kebijakan belanja dalam kerangka pertumbuhan inklusif diarahkan guna meraih tingkat output yang optimal, pengangguran yang rendah dan redistribusi pendapatan yang merata. Sementara kebijakan penerimaan yang didominasi oleh perpajakan digunakan untuk mencapai distribusi pendapatan dan kekayaan yang adil, alokasi sumber daya yang efisien dan stabilisasi ekonomi (Musgrave dan Musgrave, 1989).

Nallari dan Griffith (2011) mengungkapkan ada bukti yang kuat bahwa peningkatan belanja modal fisik dan manusia dapat mengurangi kemiskinan, di samping pertumbuhan ekonomi. Peranan belanja modal fisik dan manusia tidak saja berfungsi dalam kondisi ekonomi yang normal, lebih dari itu, kedua belanja tersebut sangat berguna ditengah kondisi pengetatatan anggaran (konsolidasi fiskal). Bahkan, belanja modal fisik dan manusia memiliki dampak positif terhadap aktivitas ekonomi dalam jangka panjang dibandingkan dengan alternatif kebijakan lain seperti peningkatan upah sektor publik. Belanja pemerintah di bidang pendidikan dan kesehatan berkontribusi terhadap perbaikan kesejahteraan masyarakat dan peningkatan produktivitas tenaga kerja.

Berbeda dengan belanja pemerintah, peran pemerintah melalui perpajakan kurang efektif dalam menciptakan pertumbuhan inklusif di negara berkembang. Besley dan Persson (2014) menyebutkan bahwa peranan pemerintah tidak efektif dikarenakan jumlah pajak yang dikumpulkan sangat kecil. Di negara berkembang, memperluas basis pajak penghasilan hampir mustahil dilakukan dengan karakter sektor informal yang besar. Hal ini mengindikasikan bahwa elastisitas pendapatan kena pajak berkenaan dengan tingkat pajak jauh lebih tinggi daripada sebaliknya-yaitu, ketika pemerintah di negara berkembang dengan sektor informal yang besar mencoba menaikkan pajak, penghasilan kena pajak dilaporkan kepada pemerintah mungkin akan turun secara substansial.

Penjelasan lain mengenai ketidakefektifan peran pemerintah melalui perpajakan dilihat dari ciri kelompok pendapatan di negara berkembang. Orang kaya di negara berkembang, umumnya memiliki cara untuk menghindari pajak yang tinggi atas penghasilan mereka. Bahkan, membebaskan beberapa barang pokok dari pajak konsumsi (pajak penjualan atau PPN) mungkin tidak memberikan manfaat terhadap orang miskin, karena orang kaya mampu mengeluarkan uang secara absolut lebih besar pada barang yang dikecualikan, oleh karenanya mereka mendapatkan keuntungan terbesar. Dalam kasus tersebut, pencabutan pembebasan tersebut dapat menghasilkan pendapatan yang bisa dikeluarkan dengan cara yang lebih berpihak kepada orang miskin (Nallari dan Griffith, 2011).

\section{STUDI TERDAHULU}

Studi terdahulu yang membahas kebijakan fiskal dan implikasinya terhadap pertumbuhan inklusif menggunakan benchmarking study. Heshmati et al (2014) misalnya, menggunakan negara anggota OECD sebagai benchmark guna memberikan rekomendasi kebijakan fiskal yang relevan dalam mempromosikan pertumbuhan inklusif di negara Asia. Hasilnya, bantuan pemerintah kepada kaum miskin dan rentan dapat menjadi alat yang efektif untuk mencapai pertumbuhan inklusif di Asia. Hal ini kemudian dilengkapkan oleh Lee dan Park (2014) melalui pengalaman empiris di Amerika Latin. Untuk menerapkan cash conditional transfer (CCT) secara intensif di Asia, harus dilakukan secara hati-hati sebab pertumbuhan ekonomi di Asia relatif lebih cepat daripada Amerika Latin. Oleh karena itu, berdasarkan temuan Estrada et al (2014), pertumbuhan inklusif harus tetap memperhitungkan kondisi kesinambungan fiskal di negara Asia.

Selain menggunakan benchmarking study, pendekatan yang paling sering digunakan untuk mengukur dampak kebijakan fiskal melalui analisis insiden fiskal. David dan Petri (2013) membuktikan bahwa program perlindungan sosial telah membantu menurunkan kemiskinan dan ketimpangan di Mauritius. Sungguh pun demikian, value added tax (VAT) memiliki dampak yang minimal dalam mengurangi ketimpangan. Lebih mengejutkan, Higgins dan Pereira (2014) menemukan pajak tidak langsung yang harus dibayar oleh kelompok rumah tangga miskin di Brazil lebih besar daripada manfaat subisidi yang diterima dari pemerintah.Pada titik ini, kebijakan fiskal sulit untuk mencapai pertumbuhan inklusif, jika tidak dikatakan eksklusif. 
Jika analisis insiden fiskal menggunakan data mikro level rumah tangga, kebijakan fiskal juga dapat dilihat dampaknya melalui interaksi antarvariabel makroekonomi.Dengan menggunakan Panel Vector Autoregression (PVAR), Hur (2014) menyimpulkan bahwa pengeluaran kesehatan dan pendidikan mampu menanggulangi ketimpangan pendapatan pada negara anggota ADB dibandingkan dengan negara anggota OECD. Dalam hal ini, efek distribusi dari pengelauran fiskal terjadi pada jangka panjang.Selain itu, Kolawole (2016) menggunakan Auto-regressive Distributed Lag (ARDL) untuk menguji hubungan antara pengeluaran pemerintah dan pertumbuhan inklusif. Secara garis besar, belanja kesehatan, kebebasan ekonomi, public resource index, dan pertumbuhan PDB riil secara signifikan dan positif berpengaruh terhadap pertumbuhan inklusif dalam jangka panjang, meskipun hanya pertumbuhan PDB riil yang berpengaruh dalam jangka pendek.

Dengan mempertimbangkan penelitian sebelumnya, implikasi kebijakan fiskal terhadap pertumbuhan ekonomi pada penelitian ini dilihat dalam interaksi antarvariabel makroekonomi. Benchamarking study tidak digunakan sebab penelitian ini tidak bermaksud mengkomparasi kebijakan fiskal antarnegara. Akan tetapi, penelitian ini hendak membandingkan strategi kebijakan fiskal pada Era Orde Baru dan Era Reformasi, dengan institusi ekonomi politik yang berbeda (lihat Rao, 2011). Kemudian, analisis insiden fiskal tidak digunakan sebab hanya memotret perilaku ekonomi secara insidental. Padahal penelitian ini di setting guna menjelaskan kebijakan fiskal dan pertumbuhan inklusif selama periode waktu 1981-2016.

\section{METODE PENELITIAN}

Penelitian ini menggunakan persamaan simultan dengan metode estimasi parameter 3SLS (Three-Stage Least Square). Metode estimasi 3SLS digunakan karena informasi variabel endogen dalam model korelasi contemporaneous tidak diperhitungkan dalam metode persamaan tunggal, sehingga interpretasinya kurang tepat. Jika dibandingkan dengan model persamaan simultan lainnya, seperti 2SLS yang bersifat Limited Information, metode 3SLS bersifat Full Information dimana model persamaan simultan menggunakan seluruh informasi yang ada. Dengan demikian, metode 3SLS memberikan estimasi yang konsisten dan estimasi yang secara asimptotik lebih efisien (Hausman, 1974).

Lebih lanjut, penelitian ini meredefinisi konsep pertumbuhan inklusif yang ditawarkan oleh Ramos et al (2013) dan Ali dan Son (2007). Pertumbuhan inklusif yang dimaksud mengarah pada pertumbuhan ekonomi yang memuat dimensi perluasan peluang ekonomi (new economic opportunity), pembagian manfaat yang meluas (benefit sharing), dan keikutsertaan seluruh masyarakat (participation) dalam aktivitas ekonomi. Dengan kata lain, pertumbuhan ekonomi suatu negara dapat dikatakan inklusif, apabila pertumbuhan ekonomi tinggi diringi dengan tingkat kemiskinan dan pengangguran yang rendah.

Sementara itu, kebijakan fiskal dalam mendorong pertumbuhan inklusif dapat dilihat baik pada sisi belanja maupun penerimaan. Kebijakan fiskal dari sisi belanja yang dianggap mampu mendorong pertumbuhan ekonomi mencakup belanja pendidikan, kesehatan, dan infrastruktur, seturut dengan indikator belanja yang digunakan oleh Santosa (2013) dan Hur (2014). Sementara itu, kebijakan fiskal dari penerimaan mencakup penerimaan pajak merujuk pada Engen dan Skinner (1992). Terakhir, khusus untuk belanja infrastruktur, dianggap berdampak terhadap pengurangan pengangguran.

Model persamaan simultan dalam penelitian ini diformulasikan ke dalam tiga persamaan mencakup diantaranya: (i) persamaan pertumbuhan ekonomi; (ii) persamaan pengangguran; dan (iii) persamaan kemiskinan. Adapun model persamaan yang dimaksud dapat dituliskan sebagai berikut:

(i) Persamaan Pertumbuhan Ekonomi



(ii) Persamaan Pengangguran

$$
\begin{aligned}
\mathrm{UNE}_{\mathrm{t}}= & \beta_{0}+\beta_{1} \mathrm{GRO}_{\mathrm{t}}+\beta_{2} \mathrm{SPE}_{-} \mathrm{INF}_{\mathrm{t}}+\alpha_{3} \mathrm{D}_{-} \mathrm{REFO}^{*} \mathrm{SPE}_{-} \mathrm{INF}_{\mathrm{t}}+\alpha_{4} \mathrm{POP}_{\mathrm{t}}+\mu_{\mathrm{t}} \\
& \text { dimana; } \\
& \beta_{1,} \beta_{2,} \beta_{3}<0 ; \beta_{4}>0 .
\end{aligned}
$$

(iii) Persamaan Kemiskinan

$$
\begin{aligned}
\mathrm{POV}_{\mathrm{t}}=\quad & \gamma_{0}+\gamma_{1} \mathrm{GRO}_{\mathrm{t}}+\gamma_{2} \mathrm{UNE}_{\mathrm{t}}+\gamma_{3} \mathrm{AGRI}_{\mathrm{t}}+\nu_{\mathrm{t}} \\
& \text { dimana; } \\
& \gamma_{1}, \gamma_{3}<0 ; \gamma_{2}>0 .
\end{aligned}
$$


Tabel 1. Definisi Operasional Variabel

\begin{tabular}{|c|c|c|c|}
\hline \multicolumn{2}{|l|}{ No. } & \multirow{2}{*}{ Satuan } & \multirow{2}{*}{ Definisi Variabel } \\
\hline \multicolumn{2}{|c|}{ Variabel Kebijakan Fiskal } & & \\
\hline 1. & Belanja pendidikan (SPE_EDU) & $\%$ & $\begin{array}{l}\text { Rasio belanja pemerintah sektor pendidikan terhadap } \\
\text { PDB }\end{array}$ \\
\hline 2. & Belanja kesehatan (SPE_HEL) & $\%$ & $\begin{array}{l}\text { Rasio belanja pemerintah sektor kesehatan terhadap } \\
\text { PDB }\end{array}$ \\
\hline 3. & $\begin{array}{l}\text { Belanja infrastruktur dasar } \\
\text { (SPE_INF) }\end{array}$ & $\%$ & $\begin{array}{l}\text { Rasio belanja pemerintah sektor infrastruktur dasar } \\
\text { (mencakup fungsi perhubungan, perumahan, dan } \\
\text { fasilitas umum) terhadap PDB }\end{array}$ \\
\hline 4. & Penerimaan Pajak (TAX) & $\%$ & Rasio total penerimaan pajak terhadap PDB \\
\hline \multicolumn{4}{|c|}{ Variabel Pertumbuhan Inklusif } \\
\hline 5. & Pertumbuhan Ekonomi (GRO) & $\%$ & Pertumbuhan PDB Atas Dasar Harga Konstan (ADHK) \\
\hline 6. & Pengangguran (UNE) & $\%$ & $\begin{array}{l}\text { Persentase jumlah pengangguran terhadap jumlah } \\
\text { angkatan kerja }\end{array}$ \\
\hline 7. & Kemiskinan (POV) & $\%$ & $\begin{array}{l}\text { Persantase penduduk yang berada di bawah garis } \\
\text { kemiskinan }\end{array}$ \\
\hline \multicolumn{4}{|c|}{ Variabel Dummy } \\
\hline 8. & $\begin{array}{l}\text { Dummy Era Reformasi } \\
\text { (D_REFO) }\end{array}$ & $\%$ & $\begin{array}{l}1=\text { Era Reformasi } \\
0=\text { Era Orde Baru }\end{array}$ \\
\hline \multicolumn{4}{|c|}{ Variabel Kontrol } \\
\hline 9. & Angkatan Kerja (LAB) & juta jiwa & $\begin{array}{l}\text { Jumlah penduduk usia kerja (15 tahun dan lebih) yang } \\
\text { bekerja, atau punya pekerjaan namun sementara tidak } \\
\text { bekerja dan pengangguran. }\end{array}$ \\
\hline 10. & Laju Populasi (POP) & $\%$ & Laju pertumbuhan penduduk secara de facto \\
\hline 11. & Share Sektor Pertanian (AGRI) & $\%$ & Rasio PDB sektor pertanian terhadap total PDB \\
\hline
\end{tabular}

Sumber: Data Diolah oleh Penulis.

Oleh karena data yang digunakan pada penelitian ini adalah data time series (runtut waktu) selama periode 1981-2016, maka penelitian ini perlu melewati uji stasioneritas dan uji kointegrasi terlebih dahulu sebelum melakukan estimasi persamaan simultan. Pada dasarnya, uji stasioneritas menekankan bahwa data yang digunakan tidak mengandung unit root. Pendeteksian variabel yang mengandung unit root dapat dilakukan melalui Uji Augmented Dickey-Fuller (ADF), yang sebelumnya merupakan pengembangan dari Uji DickeyFuller. Uji ADF sendiri menghipotesiskan bahwa data time series mengalami persoalan unit root sehingga estimasi yang dihasilkan bersumber dari model ekonometrika yang menyesatkan (misleading). Model ekonometrika yang menyesatkan dapat berupa regresi lancing (spurious regression), dimana hasil estimasi seolah-olah memiliki tingkat signifikansi dan koefisien determinasi yang tinggi.

Uji kointegrasi sendiri dimaksudkan untuk menindaklanjuti analisis data time series dalam keadaan yang tidak stasioner. Secara ekonomi, kedua variabel bisa disebut terkointegrasi apabila memiliki hubungan jangka panjang, atau keseimbangan antara keduanya. Dengan demikian, apabila terjadi guncangan dalam perekonomian, maka dalam jangka panjang terdapat kekuatan yang mendorong ekonomi untuk kembali ke kondisi keseimbangannya, atau bisa jadi membentuk keseimbangan baru. Uji kointegrasi yang digunakan pada penelitian ini merujuk pada metode yang ditawarkan Engle dan Grenger (1987), dimana residual dari persamaan yang diestimasi harus dalam keadaaan yang stasioner pada level.

\section{E. HASIL DAN DISKUSI}

\section{Hasil Penelitian}

\section{Uji Stasioneritas}

Pada level, hanya terdapat dua variabel yang berada pada kondisi stasioner yakni variabel pertumbuhan ekonomi (GRO) dan belanja kesehatan (SPE_HLT). Dengan kondisi seperti itu, perlu dilakukan uji lebih lanjut dengan meningkatkan derajat integrasi pada $1^{\text {st }}$ Difference. Pada $1^{\text {st }}$ Difference, seluruh variabel stasioner, kecuali variabel laju populasi (POP). Dengan kondisi variabel POP yang tidak stasioner, perlu dilakukan uji kointegrasi. 
Tabel 2. Ringkasan Hasil Uji Stasioneritas

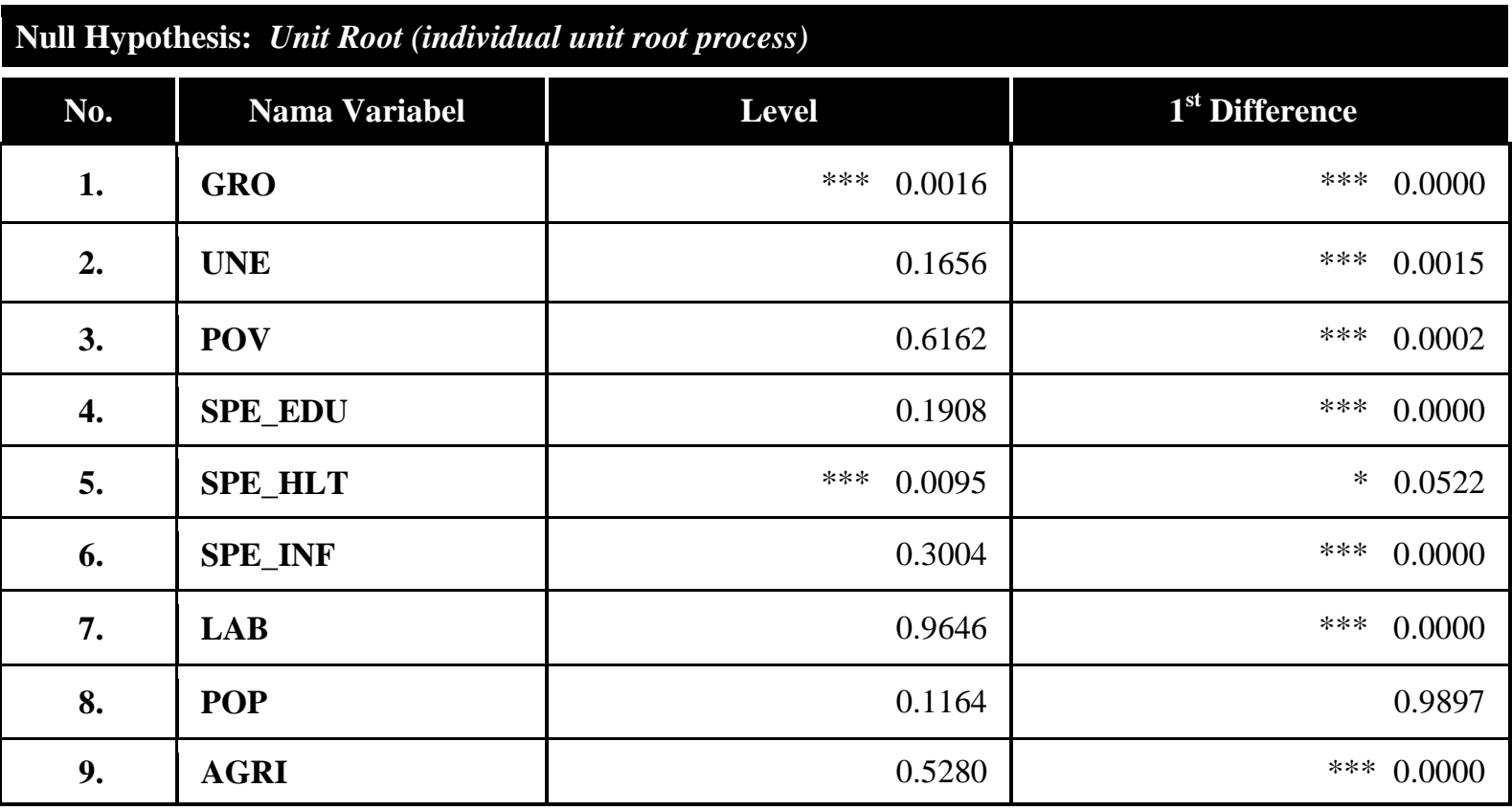

Sumber: Data Diolah dari EVIEWS9.

Keterangan: *) Signifikan pada tingkat kesalahan estimasi $10 \%$

**) Signifikan pada tingkat kesalahan estimasi $5 \%$

***) Signifikan pada tingkat kesalahan estimasi $1 \%$

\section{Uji Kointegrasi}

Meskipun masih ada variabel yang tidak stasioner, uji kointegrasi tetap dapat dilakukan dengan catatan, variabel yang tidak stasioner bisa terkointegrasi pada saat dimasukkan ke dalam persamaan (Engle dan Grenger, 1987). Hal ini kemudian dilengkapkan oleh Ariefianto (2012) bahwa suatu set variabel bisa saja terdeviasi dari pola ekulibrium namun demikian diharapkan terdapat suatu mekanisme jangka panjang yang mengembalikan variabel-variabel yang dimaksud kembali pada pola ekulibriumnya.

Hasil pengujian menunjukkan bahwa nilai probabilitas seluruh residual persamaan lebih kecil daripada tingkat estimasi kesalahan. Dari hasil tersebut, dapat disimpulkan bahwa variabel-variabel dalam setiap persamaan terkointegrasi pada derajat yang sama. Dengan kata lain, variabel independen dan variabel dependen memiliki hubungan atau keseimbangan jangka panjang

\section{Null Hypothesis: ECT01, ECT02, ECT03 has unit root}

\begin{tabular}{|c|l|c|c|c|}
\hline No. & \multicolumn{1}{|c|}{ Nama Persamaan } & Notasi Residual & Singkatan & Level \\
\hline 1. & $\begin{array}{l}\text { Persamaan } \\
\text { Pertumbuhan } \\
\text { Ekonomi }\end{array}$ & $\varepsilon_{\mathrm{t}}$ & ECT01 & $* * * 0.0009$ \\
\hline 2. & $\begin{array}{l}\text { Persamaan } \\
\text { Pengangguran }\end{array}$ & $\mu_{\mathrm{t}}$ & ECT02 & $* \mathbf{0 . 0 5 4 3}$ \\
\hline 3. & $\begin{array}{l}\text { Persamaan } \\
\text { Kemiskinan }\end{array}$ & $v_{\mathrm{t}}$ & ECT03 & $* * \mathbf{0 . 0 3 9 0}$ \\
\hline
\end{tabular}

Sumber: Data Diolah dari EVIEWS9.

Keterangan: *) $\quad$ Signifikan pada tingkat kesalahan estimasi $10 \%$

**) Signifikan pada tingkat kesalahan estimasi $5 \%$

***) Signifikan pada tingkat kesalahan estimasi $1 \%$. 


\section{Hasil Estimasi Persamaan Simultan}

Pada persamaan pertumbuhan ekonomi, variabel yang berpengaruh signifikan terhadap pertumbuhan ekonomi adalah variabel belanja pendidikan di Era Orde Baru, belanja pendidikan di Era Reformasi, belanja kesehatan di Era Orde Baru, belanja kesehatan di Era Reformasi, dan angkatan kerja. Variabel-variabel yang signifikan ini memiliki koefisien arah sesuai dengan yang diekspektasikan, kecuali, variabel belanja pendidikan Era Orde Baru dan belanja kesehatan Era Reformasi. Sementara itu, variabel penerimaan pajak dan angkatan kerja tidak berpengaruh signifikan terhadap pertumbuhan ekonomi.

Lebih lanjut, pada persamaan pengangguran dan kemiskinan seluruh variabel independen signifikan berpengaruh terhadap masing-masing variabel dependen yakni pengangguran dan kemiskinan. Pada persamaan pengangguran, hampir seluruh variabel memiliki koefisien arah yang tidak sesuai dengan yang diharapkan, kecuali variabel belanja infrastruktur pada Era Orde Baru. Pada persamaan kemiskinan, hanya variabel pertumbuhan ekonomi saja yang mempunyai koefisien arah yang sesuai dengan yang diharapkan.

Tabel 2. Ringkasan Hasil Estimasi Persamaan Simultan 3SLS

\begin{tabular}{|c|c|c|c|c|c|}
\hline Variabel & Koefisien & Standard Error & $\mathbf{Z}$ & \multicolumn{2}{|c|}{ Prob $>|Z|$} \\
\hline \multicolumn{6}{|c|}{ Persamaan Pertumbuhan Ekonomi (Variabel Dependen: GRO) } \\
\hline Konstanta & 32.13659 & 13.90123 & 2.31 & ** & 0.021 \\
\hline SPE_EDU & -9.738306 & 3.525882 & -2.76 & $* * *$ & 0.006 \\
\hline D_REFO*SPE_EDU & 16.02357 & 5.040618 & 3.18 & $* * *$ & 0.001 \\
\hline SPE_HLT & 43.50128 & 14.35849 & 3.03 & $* * *$ & 0.002 \\
\hline D_REFO*SPE_HLT & -45.96653 & 15.96 & -2.88 & $* * *$ & 0.004 \\
\hline SPE_INF & 0.7170147 & 0.5018221 & 1.43 & & 0.153 \\
\hline TAX & -0.6305192 & 0.4198091 & -1.50 & & 0.133 \\
\hline LAB & -0.2419183 & 0.0981728 & -2.46 & $* *$ & 0.014 \\
\hline \multicolumn{6}{|c|}{ Persamaan Pengangguran (Variabel Dependen: UNE) } \\
\hline Konstanta & 9.882917 & 1.782762 & 5.54 & $* * *$ & 0.000 \\
\hline GRO & 0.0288351 & 0.1066375 & 0.27 & * & 0.087 \\
\hline SPE_INF & -0.4817903 & -0.2072119 & -2.33 & $* *$ & 0.020 \\
\hline D_REFO*SPE_INF & 2.288119 & 0.5843848 & 3.92 & $* * *$ & 0.000 \\
\hline POP & -3.165413 & 1.022364 & -3.10 & $* * *$ & 0.002 \\
\hline \multicolumn{6}{|c|}{ Persamaan Kemiskinan (Variabel Dependen: POV) } \\
\hline Konstanta & -17.93572 & 5.915688 & -3.03 & $* * *$ & 0.002 \\
\hline GRO & -0.3973441 & 0.1980764 & -2.01 & $* *$ & 0.045 \\
\hline UNE & 1.614326 & 0.3597585 & 4.49 & $* * *$ & 0.000 \\
\hline AGRI & 1.586353 & 0.2152436 & 7.37 & $* * *$ & 0.000 \\
\hline
\end{tabular}

Sumber: Data Diolah dari STATA10.

Keterangan: *) Signifikan pada tingkat kesalahan estimasi $10 \%$

**) Signifikan pada tingkat kesalahan estimasi 5\%

***) Signifikan pada tingkat kesalahan estimasi $1 \%$ 


\section{Diskusi}

\section{Pertumbuhan Inklusif: Hubungan antara Pertumbuhan Ekonomi, Pengangguran dan Kemiskinan}

Dalam penelitian ini, terdapat tiga hubungan yang dapat didentifikasi guna menentukan inklusivitas pertumbuhan ekonomi di Indonesia meliputi: (i) hubungan antara pertumbuhan ekonomi dan pengangguran; (ii) hubugan antara pengangguran dan kemiskinan; dan (iii) hubungan antara pertumbuhan ekonomi dan kemiskinan. Hubungan tersebut kemudian mengarah pada temuan kunci di dalam penelitian ini.

Temuan pertama yakni pertumbuhan ekonomi cenderung direspon dengan peningkatan pengangguran. Ada dua kemungkinan yang menyebabkan fenomena tersebut terjadi. Pertama, kondisi ini sejalan dengan teori produksi sederhana. Di dalam teori produksi, guncangan teknologi pada titik tertentu mampu memperluas penyerapan tenaga kerja sebab teknologi yang digunakan komplementer dengan kebutuhan tenaga kerja. Akan tetapi, guncangan teknologi selanjutnya dapat menurunkan jumlah kebutuhan tenaga kerja sehingga meningkatkan pengangguran secara agregat. Guncangan teknologi semacam ini bersifat padat modal (capital intensive). Di Indonesia, ada indikasi bahwa pertumbuhan ekonomi cenderung mengarah ke struktur produksi yang bersifat padat modal (capital intensive). Kemungkinan pertama ini sejalan dengan penelitian Dartanto (2013).

Kedua, hubungan antara pertumbuhan ekonomi dan pengangguran dalam kasus Indonesia bisa jadi kompleks. Islam dan Nazara (2000) menjelaskan kompleksitas hubungan tersebut mengikuti apa yang disebut sebagai hipotesis "unemployment as luxury". Sebagai contoh, dengan tidak adanya tunjangan pengangguran yang memadai di Indonesia, pengangguran selama masa kontraksi menjadi sebuah "kemewahan" yang hanya bisa dinikmati oleh mereka yang memiliki pendapatan di luar pekerjaan yang memadai. Dengan anggapan menjadi penganggur bukan merupakan pilihan yang tepat, tenaga kerja yang sebelumnya bekerja di sektorsektor yang terimbas resesi besar pada tahun 1997, kemudian berpindah ke sektor pertanian dan sektor informal daripada tetap "secara terbuka menganggur". Fenomena perpindahan tenaga kerja ini dapat disebut sebagai realokasi tenaga kerja.

Selanjutnya, temuan kedua yakni tingkat pengangguran direspon oleh peningkatan kemiskinan. Secara teoritis, hubungan ini dapat ditelusuri melalui peran pasar tenaga kerja. Tingkat pengangguran yang secara keseluruhan lebih tinggi akan mempengaruhi jumlah orang yang berada di bawah garis kemiskinan. Mayoritas rumah tangga di negara berkembang mengandalkan pendapatan dari pasar tenaga kerja, sehingga apabila terjadi peningkatan pengangguran, maka dapat menggerus pendapatan yang cukup besar dari rumah tangga bersangkutan (Powers, 1995).

Temuan ketiga yakni pertumbuhan ekonomi di Indonesia yang cenderung direspon dengan penurunan kemiskinan. Dengan kata lain, peningkatan aktivitas ekonomi telah berpihak kepada kelompok miskin (propoor) tanpa melalui pasar tenaga kerja. Ada dua saluran yang menjelaskan pertumbuhan ekonomi yang berpihak langsung kepada kelompok miskin (pro-poor growth) di Indonesia. Pertama, saluran langsung, dimana dampak dari peningkatan aktivitas ekonomi dapat dirasakan langsung oleh kelompok miskin. Contoh dari saluran langsungini mencakup peningkatan aktivitas ekonomi pada sektor infrastruktur dan layanan dasarseperti peningkatan kualitas pendidikan, layanan kesehatan, perbaikan sanitasi, dan pembangunan jalan pedesaan. Saluran langsung ini biasanya menyasar kelompok miskin yang memiliki akses rendah sehingga mereka tidak mampu melakukan perbaikan terhadap tingkat pendapatannya.

Kedua, pertumbuhan ekonomi yang menurunkan kemiskinan melalui saluran pasar.Saluran pasar ini biasanya dikaitkan dengan hipotesis Kuznets (1955) yang menghubungkan antara pendapatan per kapita dan tingkat ketimpangan dalam distribusi pendapatan. Tidak jauh berbeda dengan hipotesis Kuznets (1955), pada awalnya peningkatan pendapatan per kapita meningkatkan kemiskinan, pada titik tertentu terjadi efek rembesan ke bawah yang memungkinkan manfaat yang diterima kelompok kaya tesebar ke kelompok miskin. Efek rembesan ke bawah melalui pertumbuhan ekonomi, tidak hanya menempatkan kelompok miskin mendapat keuntungan dari pertumbuhan pendapatan nominalnya, tetapi juga dari teknologi produksi yang membuat barang yang mereka konsumsi lebih murah di pasar, sehingga meningkatkan daya beli mereka. Pada akhirnya, daya beli yang meningkat di atas garis kemiskinan mampu mengubah status mereka yang miskin.

Dengan merujuk pada tiga temuan tersebut, pertumbuhan inklusif di Indonesia dapat dijelaskan melalui dua jalur, yakni: (i) dampak pertumbuhan ekonomi secara langsung (direct effect) terhadap kemiskinan, dan (ii) dampak pertumbuhan ekonomi secara tidak langsung (indirect effect) melalui pengangguran terhadap kemiskinan. Pertama, dampak pertumbuhan ekonomi secara langsung dapat menurunkan kemiskinan. Pada jalur ini, pertumbuhan ekonomi berada pada track yang benar dalam mewujudkan pertumbuhan inklusif. Peningkatan aktivitas ekonomi tanpa melalui pasar tenaga kerja di Indonesia mengindikasikan bahwa peningkatan pendapatan yang mampu menurunkan kemiskinan bisa bersumber dari self-employee. Adanya selfemployee ini diindikasikan oleh tumbuhnya industri kecil menengah (IKM) yang mampu menjadi solusi peningkatan pendapatan kelompok miskin bahkan saat periode krisis. Kedua, dampak pertumbuhan ekonomi secara tidak langsung melalui pengangguran direspon oleh peningkatan kemiskinan sebab efek total (efek pertumbuhan terhadap pengangguran dan efek pengangguran terhadap kemiskinan) bernilai positif. Oleh karena itu, pada jalur ini, pertumbuhan ekonomi yang tercipta masih belum memenuhi syarat pertumbuhan inklusif. 


\section{Kebijakan Fiskal Era Orde Baru dan Era Reformasi dan Implikasinya terhadap Pertumbuhan Inklusif di Indonesia}

Kebijakan fiskal yang berdampak terhadap pertumbuhan inklusif di Indonesia dapat dipetakan ke dalam lima hubungan meliputi; (i) hubungan antara belanja pendidikan dengan pertumbuhan ekonomi; (ii) hubungan antara belanja kesehatan dengan pertumbuhan ekonomi; (iii) hubungan antara belanja infrastruktur dengan pertumbuhan ekonomi; (iv) hubungan antar penerimaan pajak dengan pertumbuhan ekonomi; dan (v) hubungan antara belanja infrastruktur dengan pengangguran. Dari hubungan antarvariabel tersebut, selanjutnya menghasilkan lima temuan penting.

Temuan pertama, yaitu belanja pendidikan di Era Orde Baru direspon dengan penurunan pertumbuhan ekonomi, sementara di Era Reformasi, belanja pendidikan direspon dengan peningkatan pertumbuhan ekonomi. Hal ini mengindikasikan bahwa pada Era Reformasi, kepekaan anggaran terhadap perbaikan kualitas pendidikan sebagai mesin pertumbuhan ekonomi (engine of growth) lebih tinggi dibandingkan Era Orde Baru. Kepekaan anggaran terhadap perbaikan kualitas pendidikan di Era Reformasi ini juga tidak terlepas dari status belanja pendidikan sebagai mandatory spending. Mandatory spending ini mencakup hak-hak setiap warga negara untuk memperoleh akses pendidikan yang bermutu dan terjangkau. Mandatory spending dalam belanja pendidikan mencakup dana pendidikan selain gaji pendidik dan biaya pendidikan kedinasan yang dialokasikan minimal $20 \%$ dari Anggaran Pendapatan dan Belanja Negara (APBN).

Temuan kedua, yaitu belanja kesehatan di Era Orde Baru direspon dengan peningkatan pertumbuhan ekonomi, sementara di Era Reformasi, belanja kesehatan direspon dengan penurunan pertumbuhan ekonomi. Hal ini mengindikasikan bahwa sistem kesehatan nasional di Era Orde Baru lebih efektif mengingat sistem yang digunakan lebih terintegrasi. Hal ini mengindikasikan bahwa sistem kesehatan nasional di Era Orde Baru lebih efektif mengingat sistem yang digunakan lebih terintegrasi. Santosa (2013) mencontohkan dalam kasus di Jawa Timur, penyediaan barang publik (termasuk layanan kesehatan) bisa jadi tidak efisien di Era Reformasi. Ada tiga alasan yang mendasari ketidakefisienan tersebut, yakni: (i) gagalnya pemerintah mengidentifikasi barang publik yang dibutuhkan oleh masyarakat; (ii) gagalnya pemerintah mengenali adanya efek eksternalitas atau benefit-spillover; dan (iii) gagalnya pemerintah mengidentifikasi barang pubik yang membutuhkan skala ekonomi tertentu. Pencapaian program kesehatan di Era Orde Baru lebih kontras dari apa yang ditemukan di Era Reformasi. Piet (2003) mencatat keberhasilan program kesehatan di Era Orde Baru melalui program keluarga berencana (family planning). Piet (2003) menyebutkan bahwa program keluarga berencana di Era Orde Baru dikenal luas sebagai salah satu program yang berhasil di dunia. Selain program keluarga berencana, Kaputra (2013) menyebutkan bahwa Puskesmas dan Posyandu telah mampu menjangkau masyarakat desa sehingga program kesehatan dapat berjalan secara berkesinambungan di Era Orde Baru..

Temuan ketiga, yaitu belanja infrastruktur baik di Era Orde Baru maupun di Era Reformasi tidak memiliki dampak terhadap pertumbuhan ekonomi. Fenomena ini bisa dijelaskan dengan dua argumen. Pertama, peningkatan belanja infrastruktur memang tidak dirasakan langsung pada saat infrastruktur tersebut dibangun. Peningkatan belanja infrastruktur pada saat itu, paling tidak, hanya diarahkan untuk mencapai tingkat output yang sama, atau mencegah belanja infrastruktur berpotensi menekan pertumbuhan ekonomi.

Kedua, kenaikan stok dan penurunan rata-rata usia infrastruktur bertepatan dengan periode peningkatan belanja tahunan infrastruktur pemerintah yang cukup besar. Pengeluaran untuk infrastruktur dapat mencakup pengeluaran untuk memperoleh aset infrastruktur baru atau untuk meningkatkan dan/atau memperbaiki infrastruktur yang ada. Namun, pengeluaran tahunan tidak termasuk biaya pemeliharaan infrastruktur yang ada. Dengan demikian, peningkatan belanja infrastruktur tidak memiliki dampak atau netral terhadap pertumbuhan ekonomi (Lammam dan MacIntyre, 2017)

Temuan keempat, yaitu penerimaan pajak baik di Era Orde Baru maupun di Era Reformasi tidak memiliki dampak terhadap pertumbuhan ekonomi. Temuan ini menarik, mengingat bahwa secara gradual, Indonesia telah melewati berbagai rangkaian reformasi perpajakan masing-masing pada tahun 1983, 1994, 2000, dan 2004-2005 (Suhardjito, $\mathrm{tt}$ ). Oleh karenanya, penerimaan pajak yang tidak berdampak ini mesti dimaknai secara hati-hati. Temuan ini bukan berarti mengkonfirmasi bahwa reformasi sistem perpajakan di Indonesia telah mengarah pada good tax policy, meminjam istilah Hamid (2002), dimana pajak bersifat netral dan tidak memberikan distorsi terhadap aktivitas ekonomi.

Penerimaan pajak yang tidak berdampak terhadap pertumbuhan ekonomi ini lebih disebabkan oleh proses bisnis yang tidak banyak berubah (business as usual) meskipun telah dilakukan reformasi perpajakan berulangkali. Effendi (2016) menyatakan bahwa, dengan proses bisnis yang hampir sama, terdapat kemungkinan penerimaan pajak tidak akan selalu terpenuhi dalam beberapa tahun ke depan. Dengan begitu, bisa disimpulkan bahwa penerimaan pajak selama periode 1981-2016, tidak mendistorsi perekonomian, tetapi tidak pula menjadi tulang punggung dalam mendorong pertumbuhan ekonomi.

Temuan terakhir, yaitu belanja infrastruktur di Era Orde Baru direspon dengan penurunan pengangguran, sementara di Era Reformasi, belanja infrastruktur direspon dengan peningkatan pengangguran. Hal ini mengindikasikan bahwa belanja infrastruktur di Era Orde Baru lebih bersifat labour intensive, jika dibandingkan dengan Era Reformasi. Hal ini sangat beralasan sebab aktivitas ekonomi dan sektor produksi di Era Orde Baru 
diarahkan guna mencapai jalur pertumbuhan berbasis labour intensive (Hill, 2000). Oleh karenanya, bukan hanya sektor industri, investasi pemerintah diarahkan pada pembangunan infrastruktur, terutama pembangunan jaringan jalan (Hill dan Narjoko, 2010; Ricklefs, 2001), yang notabene mampu menyerap tenaga kerja dalam skala yang cukup besar. Proyek-proyek yang bersifat labour intensive inilah yang membedakan dampak belanja infrastruktur di Era Orde Baru, jika dibandingkan dengan Era Reformasi.

\section{E. KESIMPULAN DAN REKOMENDASI KEBIJAKAN}

\section{Kesimpulan}

Berdasarkan temuan penelitian sebelumnya, dapat ditarik beberapa kesimpulan antara lain:

1. Dampak pertumbuhan ekonomi secara langsung (direct effect) dapat menurunkan kemiskinan, sementara dampak pertumbuhan ekonomi secara tidak langsung (indirect effect) melalui pengangguran belum mampu menurunkan kemiskinan. Oleh karenanya, pertumbuhan ekonomi di Indonesia masih belum dapat dikatakan inklusif; dan,

2. Kebijakan fiskal Era Orde Baru dan Era Reformasi memiliki implikasi yang berbeda terhadap pertumbuhan inklusif di Indonesia. Peningkatan pertumbuhan ekonomi bersumber dari belanja kesehatan di Era Orde Baru dan belanja pendidikan di Era Reformasi. Sementara itu, penurunan pengangguran berasal dari belanja infrastruktur di Era Orde Baru.

\section{Rekomendasi Kebijakan}

Berdasarkan kesimpulan sebelumnya, ada beberapa saran dan rekomendasi kebijakan yang diajukan oleh peneliti guna mempercepat pertumbuhan inklusif di Indonesia. Adapun saran yang dimakud antara lain:

1. Perbaikan lingkungan bisnis (business environment) yang memampukan tumbuhnya usaha baru dan merevitalisasi industri kecil menengah (IKM) yang sebelumnya telah berkembang;

2. Peningkatan produktivitas tenaga kerja melalui peningkatan kapasitas setiap masyarakat agar menjadi input yang berguna bagi produksi;

3. Belanja pendidikan harus terus diefektifkan dengan mempertahankan peningkatan belanja pendidikan lebih tinggi daripada perubahan harga (inflasi);

4. Belanja kesehatan didesain dalam sebuah sistem dan layanan kesehatan yang terintegrasi dengan mempertimbangkan permintaan barang publik terkait, eksternalitas dan skala ekonominya; dan,

5. Peran pemerintah terutama dalam menciptakan proyek-proyek yang bersifat unskilled labour-intensive masih sangat diperlukan dalam jangka menengah.

\section{DAFTAR PUSTAKA}

Ali, Ifzal., \& Hyun H. Son. 2007. Defining and Measuring Inclusive Growth: Application to The Philippines . ERD Working Paper Series No.98.

Anderson, Steve., et al.tt. Inclusive Growth Diagnostic For Indonesia. AUSAID.

Ariefianto, Moch.Doddy. 2012. Ekonometrika: Esensi dan Aplikasi dengan Menggunakan EViews. Jakarta: Penerbit Erlangga.

Besley, Timothy., \&Torsten Persson. 2014. Why Do Developing Countries Tax So Little?. Journal of Economic Perspectives, 28 (4).99-120. ISSN 0895-3309.

Biswas, Arindam. 2016. Insight on the Evolution and Distinction of Inclusive Growth. Development in Practice, 26(4), 503-516.

Dartanto, Teguh. 2013. Why is Growth Less Inclusive in Indonesia?. MPRA Paper No. 65136.

David, Antonio., \&Martin Petri. 2013. Inclusive Growth and the Inciedence of Fiscal Policy in Mauritius: Much Progress, But More Could Be Done. IMF Working Paper 13 (116), 1-27.

Effendi, Yuventus. 2016. Adopsi Teori Pertumbuhan untuk Menjamin Penerimaan Pajak yang Berkelanjutan. Dalam Amir, H., \& Hastiadi, F.F. (ed.), Dinamika Kebijakan Fiskal: Merespons Ketidakpastian Global. Jakarta: PT. Gramedia Pustaka Utama.

Engen, Eric M., \& Jonathan Skinner. 1992. Fiscal Policy and Economic Growth. NBER Working Paper (4223), 1-44.

Engle, Robert F., \&Clive W.J. Grenger. 1987. Cointegration and Error Correction: Representation, Estimation, and Testing. Econometrica, 55(22): 251-276.

Estrada, Gemma Bolotaulo., et al. 2014. Fiscal Policy for Inclusive Growth: An Overview. ADB Economics Working Paper Series (423), 1-24.

Hadi, Syamsul. 2012. Inclusive Growth in Indonesia: Myth or Reality?. East Asian Policy, 4(67).

Hamid, Edi Suandi. 2002. Hukum Pajak, Edisi kedua (revisi). Jakarta: Salemba Empat. 
Hausman, Jerry. A. 1974. Full Information Instrumental Variables Estimation of Simultaneous Equations Eystems. In Annals of Economic and Social Measurement, 3(4), 641-652

Heshmati, Almas., et al. 2014. Fiscal Policy and Inclusive Growth in Advanced Countries: Their Experience and Implications for Asia. ADB Economics Working Paper Series (422), 1-17.

Higgins, Sean., \&Claudiney Pereira. 2014. The Effects Of Brazil's Taxation and Social Spending on The Distribution of Household Income. Public Finance Review, 42(3), 346-367.

Hill, Hal. 2000. The Indonesian Economy. Cambridge, United Kingdom: Cambridge University Press.

Hill, Hal, \& Dionisius Narjoko. 2010. Managing Industrialisation in a Globalising Economy: Lessons from the Soeharto Era. Soeharto's New Order and its Legacy, 49.

Hur, Seok-Kyun. 2014. Government Spending and Inclusive Growth in Developing Asia.Asian Development Bank Economics Working Paper Series No. 415.

Islam, Iyanatul., \&Suahazil Nazara.2000. Estimating Employment Elasticiy for the Indonesian Economy. Jakarta, Indonesia: International Labour Office.

Ismail, Munawar., et al. 2014. Sistem Ekonomi Indonesia: Tafsir Pancasila dan UUD 1945. Penerbit Erlangga.

Kaputra, Iswan 2013. Pemberdayaan Masyarakat Era Otonomi Daerah. DalamSimanjuntak, B.A. (ed.) Dampak Otonomi Daerah di Indonesia: Merangkai Sejarah Politik dan Pemerintahan Indonesia. Jakarta: Yayasan Pustaka Obor Indonesia.

Kolawole, Bashir Olayinka. 2016. Government Spending and Inclusive-Growth Relationship in Nigeria: An Empirical Investigation. Zagreb International Review of Economics and Business, 19(2), 33-56.

Kuznets, Simon. 1955. Economic Growth and Income Inequality. The American Economic Review 45 (1), 1-25.

Lammam, Charles, \&Hugh MacIntyre. 2017. Myths of Infrastructure Spending in Canada.Canada: Fraser Institute.

Lee, Sang-Hyop., \&Donghyun Park. 2014. Fiscal Policy and Inclusive Growth in Latin America: Lesson for Asia. ADB Economics Working Paper Series (408), 1-19.

Musgrave, Richard.A., \&Peggy B. Musgrave. 1989. Public Finance: In Theory and Practice. New York: McGraw-Hill International.

Nallari, Raj, \&Breda Griffith. 2011. Understanding Growth and Poverty: Theory, Policy, and World Bank. Retrieved from https://openknowledge. worldbank.org/handle/ 10986/2281, July 24, 2017.

Naqvi, Syed Nawab Haide. 2012. The Idea of Inclusive Growth and Development Policy. The Pakistan Development Review, 1-21.

Piet, D. L., 2003. The Significance of Foreign Assistance to the Indonesian Family Planning Program. In Niehof and Lubis, 83-106.

Powers, Elizabeth T.1995. Inflation, Unemployment, and Poverty Revisited. In Economic Review of the Federal Reserve Bank of Cleveland, 2: 2-13.

Ramos, Raquel Almeida, et al. 2013. Mapping Inclusive Growth. IPC-IG Working PaperNo.195.

Rao, Chung-Hwa Herman. 2011. India and China: A Comparison of the Role of Sociopolitical Factors in Inclusive Growth. Economic and Political Weekly, 66, 24-28.

Ricklefs, Merle Calvin.2001. A History of Modern Indonesia Since c.1200 (3rd Edition ed.). Hampshire: Palgrave Macmillan.

Santosa, Dwi Budi. 1992. Analisis Redistribusi Pendapatan di Indonesia. Tesis tidak terpublikasi, Universitas Indonesia.

Santosa, Dwi Budi. 2013. Budget Decentralization and Economic Development Inequality among Regions in East Java. Journal of Global Business \& Economics, 7(1), 85-103.

Suhardjito. tt. Reformasi Perpajakan dalam Rangka Peningkatan Kepatuhan Wajib Pajak., Tata Kelola yang Baik, serta Kemandirian Bangsa. Forum Manajemen, 13 (3), 33-39. Diakses dari http://www.pusdiklatmigas.com/old/modules/Publikasi_Ilmiah/6.pdf pada tanggal 24 Juli 2017. 